\title{
Transformation of Challenged Students in Nigeria's Higher Education: Counseling Implication
}

\author{
F. N. Chinwe Onyilofor \\ Faculty of Education \\ Department of Educational Foundation \\ University of Nigeria, Nsukka \\ Enugu State, Nigeria
}

\begin{abstract}
This study focuses on the transformation of challenged students in Nigerian higher education: counseling implication. Descriptive survey research design was used for the study. The population of the study was 179: made up 140 challenged student counselors, and 39 professional counselors in southsouth geo-political zone of Nigeria. A 20 item researcher-developed structured questionnaire was used as instrument for data collection. The data collected was analyzed quantitatively using mean scores and standard deviation. A mean score of 2.5 and above was accepted while any mean score less that 2.5 was rejected. The findings of this study by implication were that the transformation of challenged students in Nigeria higher education cannot be over emphasized. This implies that if the professional counselor trains them well, when they graduate, they will be valuable, disciplined, and their intrinsic abilities will be fully developed. Secondly, various counselling skills, such as orientation, transformation, evaluation, managerial, creative and problem-solving skills were identified as required in the transformation of challenged students. It was therefore recommended that both government and non-government organizations should donate and equip classrooms and counselling centres where challenged students are trained with modern assistive technologies. The challenged students, expert teachers and professional counsellors should regularly be developed professionally through sponsorship and scholarships to enable them compete favourably with their counterparts all over the world.
\end{abstract}

\section{Introduction}

Education is seen as an avenue through which societies are transformed. It plays vital roles in the transmission of cultural heritage from one generation to another; in the formation of social skills and reformation of attitudes; among other functions.
According to Agarwal [1], the significant functions of education include to complete the socialization process, to transmit the cultural heritage, formation of social personality, reformation of attitudes, education for occupational placement, facilitation of skills training that are required by the economy, among others. Shaw [2] sees education as an avenue for teachers training, professional development and skill acquisition, such as the interest skills, communication skills, creative skills, problem solving skill, personal development, and career development in the teaching profession.

Similarly, Onyilofor [5], adjudges that in Nigeria education has been a major means through which societies ensure that their younger generations including the challenged students acquire the necessary skills, attitudes, professional development, and values that enable them function effectively in the society. However, Fafunwa [4], and Onyilofor [3] define education as a procedure by which challenged students develop intrinsic abilities, interest, potentialities, values and skills which enable them have changes in their daily conduct, become disciplined and well-adjusted as well as develop positive mind set in the community they find themselves. Furthermore, Onyilofor [5], adjudges that education enables challenged students to contribute to national development and solve their own problems and others with acquisition of skills inculcated while in school. The challenged students, on graduation, become independent, employer of labour, and job creators in both micro and macro industries. Nnadi [9], succinctly, supports the above assertion that education no doubt is a veritable tool for accelerated national development. The researcher declares that education brings about interconnectivity of actions through technology. Through education, countries all over the world can easily and effectively share common interests, collaborate and partner to pursue national and international goals and achieve their aspirations. This has led to the emergence of university linkages and advancement for the promotion of higher education reforms. This is made 
possible as a result of the rate of advancement in information and communication technologies (ICTs). Education made Nigeria as whole and other foreign countries to be a global village where Nigerian challenged students in higher education, ET/PC compete favorably and collaborate with their counterparts nationally and internationally through Skype, Facebook and other social media platforms. Aglazor [8] declares that, whether Nigeria's educational institutions are prepared or not, the challenged youth, like their peers worldwide are living in an increasingly globalised world. Education according to the researcher is the sharpest vehicle for transformation of the challenged students in Nigeria's higher education.

Challenged students (CS) in this paper can also be called special needs students (SNS), disabled students, handicapped students, gifted students, the dwarf, the albino, migrant, past experience and speculators (people that guess the future) (Onyilofor [2]). Challenged students refer to individuals with both single and multiple disabilities. Challenged student with single disability are; the visually challenged, stammerers, one-hand paralysis, poliomyelitis (an acute infectious virus disease marked by inflammation of nerve cells in the spinal cord causing paralysis) and river blindness. The multiple disability include: deaf and dumb, cerebral palsy (mental disabilities), unipolar disorder (people diagnosed for depression), bipolar depression (when people feel euphoria/elated or extreme irritability or agitation), autism spectrum (a group of complex developmental brain disorder caused by combination of genes and environmental influences), epilepsy and dyslexia (a learning disability that affects people in language, reading, and spelling) [9]. Onyilofor [10] states that the challenged students include the visually challenged, orthopedically impaired; hard of hearing, the deaf and dumb persons, people with dyslexia, leprosy, albinos, poliomyelitis, paralytic and gifted people. Also included in this category are the dwarf, hunch back, albinos, hard of hearing, visually challenged, bipolar, unipolar, socially disturbed, cerebral palsy victims, dyslexia, glaucoma and blurred sighted et cetera. These challenged students can be transformed by the help of ET/PC.

Transformation, is seen as a process, as the ultimate development goal of all organized societies and most importantly as the ultimate task of education (Onyilofor [3]) while Obanya [13], in support of the above assertion states that transformation is a method to achieve radical, positive and qualitative improvement and that it often has a multi dimensional impact (a single intervention impacting several interrelated issues). In transforming Nigerian higher education, there is need for change in politics, product, policies, programmes and process which are the five pivots $(5 \mathrm{ps})$ of educational process. The task should begin by changing the ideas and mind-set of challenged students to move away from a stand point of what I stand to gain to a strong desire for public service in the people's interest. Transformation is exploitation of natural resources, the choice of type of investment and orientation of technological and institutional Agwu [14]. Transformation in policy has to do with side-by-side fully participatory approach as has always been with Nigerian leaders and this participatory approach involves leaders, stakeholders with real needs. Such stakeholders include rural dwellers, traditional institutions, local to federal government, ET/PC, organization, NGOs, professional bodies, academic and organized private sectors and challenged students and their parents/guardians. In Nigeria, where the challenged students are not adequately cared for by the local, state, and federal government, challenged students always desire that their parents take care of them and sacrifice for them. However, if the parents of the challenged students are poor but work hard to be able to send their challenged students to school, they will be moved and deeply grateful. Conversely, if the parents are rich but do not take care of their challenged student, they may bear unspoken complaints. The parents' sacrifice for challenged students is clearly shown through their behavior. Accidentally, we have taught our challenged students selfish lifestyles.

This is where the professional counselor's role comes into lime light. To the challenged students, the professional counselor has to counsel them from their undesirable attitudes of having unspoken complaints to desirable attitude to open up and tell their parents where it hurts them instead of bottling up their emotions which may lead them to frustration. Professional counsellors have great roles to play in changing their (challenged students) negative lifestyles to positive lifestyles through counseling and monitoring of their attitudes. To the poor challenged student's parents who try to care and sacrifice for their challenged wards, the professional counselor has to appreciate them just to encourage them to work harder and help their challenged wards more.

The professional counselor has to sensitize the government at all level to give scholarships to challenged students, equip them with various types of assistive technologies. Also, the professional counselor has to at least twice in a year visit various institutions housing challenged students to supervise the extent of utilization of gadgets/equipment (assistive technologies) in the training of challenged students as well as monitor the functionality of these training devices and how the students are coping with their learning. These training gadgets should be regularly inspected, serviced/repaired when malfunctioned, and updated to meet up with the international standard. There is also need for provision of management and technical supports for smooth running of the training programmes. 
The federal government of Nigeria has expressed concern about the educational system which emphasizes theoretical knowledge at the expense of technical, vocational and teacher education. It has directed that teacher education be injected into the curriculum of university education. Since then it has been introduced as general studies in the higher education or university education (NUC, [15]).

\section{Significance of the Study}

Higher education is education attained after secondary education. Banya and Elu [14] pointed out that higher education stands for any type of education given at post secondary institution of learning and usually affording at the end of the course of study a named degree, diploma and certificate of higher studies. It is education that offers a number of qualifications ranging from higher national diploma and foundation degrees to honours degree as further step to post graduate programs leading to the award of Master's and Doctorate degrees [15]. Onyilofor [5] defined higher education as a place where frontiers of knowledge is developed through practical work and exercises in the $21^{\text {st }}$ century unlike in the $18^{\text {th }} \& 19^{\text {th }}$ century where theory was highly emphasized. Furthermore, Onyilofor [3], describes higher education as education provided by universities aimed at developing adroit, dexterous, skills, adept, competent, and proficient manpower; for the political, economic, and socio-cultural transformation of the nation and the society as a whole. Higher education all over the world is comprised of different fields of study for the reformation of attitudes and training of manpower required for national and economic development. Among the fields of study established in higher education is Guidance and Counselling, where expert teachers and professional counsellors are produced. These professionals are saddled with the responsibilities of developing the innate potentials of challenged students through guidance and counselling services and helping them in making career choices.

Without informed guidance and counseling many challenged students lose focus and direction. Some of the challenged students despite their handicapped condition engage in illegal activities/immoral acts such as truancy, alcoholism, drug abuse, stealing, examination malpractice, plagiarism, sexual immorality, cultism, indecent dressing, prostitution, and drop out, as a result, they lack both focus and direction resulting to total failure in life. Therefore, challenged students need guidance and counseling to study and choose career of their interest.

Guidance and counselling is a programme of study responsible for helping individuals develop their potentialities for self-actualization. Furthermore, Anyamene, Mwokolo, Anyachebelu [18] construe counseling as a form of education, which the challenged students receive from their counselors. Similarly Palmer [19] sees counseling as an educational process used in solving problems of the learner. United Nation Educational, Scientific and Cultural Organization (UNESCO, [21]) in support of the above assertion, states that counseling is actively listening to an individual's story and communicating understanding, respect and empathy: clarifying goals and assisting challenged students with the decision making process. Similarly, Onyilofor [22] emphasizes that counseling is a process by which a professional counselor helps the client to understand himself or herself better. Onyilofor [22] further advocates that counseling is the assistance a professional counselor gives to challenged students (clients) on issues of education, social-personal, and career choice. Stratton [23] sees the role of professional counselor to be most importantly one to one interviews between the career counselor and client. In addition, Obi, Oye, Mohd, and Beknice [24] in support of the above said that career counseling may involve both face to face help or may be mediated through telephone, letter, text or even the internet. Mghweno, Mghweno and Baguna [18] noted that guidance and counseling service is not a new phenomenon. In Nigeria, for instance, the counselling service was incorporated into the school systems in 1959. Consequently, incorporating guidance and counseling into the school system was to eliminate overwhelming ignorance of many challenged students on their choice of career prospects and personality maladjustment among them.

Furthermore, other roles of professional counselor include opportunities to develop knowledge in the challenged student and appreciations of themselves and others; opportunities to develop relationship skills, ethical standard and a sense of responsibility in the challenged students; opportunities to acquire skills and attitudes necessary to develop educational goals which suit the challenged students' needs, interests and abilities. Onyilofor [5] posits that the professional counselor should utilize his/her professional skills (administrative skills, thinking skills, orientation and planning skills, time management skills, technical and technological skills) for the transformation and education of challenged student in Nigerian higher education. Onyilofor [5], further states that a counselor should be a think tank and an inventive problem solver and should be able to reason properly both with the brain and the heart in the transformation of challenged students in Nigeria's higher education. The researcher further advocates that counseling enables challenged student to adjust himself to his studies by improving his study attitude and removing subject matter difficulties. This can be achieved with the assistance of professional counselors. In Nigeria, counseling generally are viewed in three categories namely; educational 
counseling, vocational counseling and socio-personal counseling. Parson in Patton \& McMahon [25, 26] categorized the role of professional counseling into three dimensions - self-analysis, occupational analysis and true reasoning. Other roles of the PC are consultation to challenged students, individuals, groups, families, couples and organizations, and research into more effective and therapeutic treatment modalities.

Special education SE is a programme designed to suit the challenged students (the socially, mentally, physically, and emotionally retarded/delayed) to oversee their overall skill development (physical, cognitive, scholastic skills). The individuals with disabilities act, IDEA [27] defines special education as "specially designed instruction, at no cost to the parents, to meet the unique needs of a challenged student. Okyere and Adam [28] as cited in Heward and Orlanry referred to special education as individually planned, systematically and carefully evaluated instruction that helps exceptional learners achieve the greatest possible personal selfsufficiency and success in the present and future environments. While Christopher [29] sees special education as unique because while little or no attention is given to $\mathrm{CS}$ in the society special education recognizes and provides comprehensive service for them. The researcher concludes that special education is specially designed and systematically organized instructions to meet the unique needs of $\mathrm{CS}$ in their various handicapping conditions/exceptionality. In addition, the researcher further opines that special education has different gadgets for different handicapping conditions for instance, Perkins Braille machines, Braille Papers, stop watch, talking watch, white cane, and Cylos are for the visually challenged.

Special education is considered as a service not a place and those services are integrated into daily routine and classroom structures, environment, curriculum and strategies are brought to the challenged students instead of renewing the challenged students to meet their individual needs (Onyilofor [5]). Furthermore, Onyilofor [5] launches that special education is an individually planned and systematically monitored arrangement of teaching procedures, adopted equipment and materials, accessible settings and other intervention designed to help learners with special needs to achieve functional education that can transform them to be self-reliant, self-employed, self-sufficient and self- actualized.

The ET/PC require professional training and development in order to effectively inculcate in the learners/challenged students the feeling of acceptance, love and care as well as the proper skills that will enable them become better citizens in their families, communities, states, national and international societies. In countries like Australia, China, Japan, USA, Canada, and Britain, both the ET and PC undergo so many transformations in the system of educating, guiding and counselling challenged students. The government of these countries supply challenged students with all manner of gadgets, infrastructure, conducive learning environments, well-equipped offices/classrooms and counseling chambers where counseling and learning can effectively take place.

The study will be of immense benefit to rural dwellers, traditional institutions, all levels of government, ET/PC, organizations, NGOS, professional bodies, academics, $\mathrm{CS}$ and their parents/guardian. Based on the foregoing, the question that remains germane is what are the counseling implication of the transformation of CS in Nigeria higher education?

The main purpose of this study is to determine counseling implication of the transformation of CS in Nigeria higher education. Specifically, the study determined:

1. The counseling implication of the transformation of challenged students in Nigeria higher education;

2. To find out various counseling skills a PC utilizes in the transformation of $\mathrm{CS}$ in Nigeria higher education.

Two research questions were postulated to guide the study:

1. What are the counseling implication of the transformation of $\mathrm{CS}$ in Nigeria higher education?

2. What are the various counseling skills a professional counselor utilizes in transformation of CS in Nigeria higher education?

\section{Research Method}

\subsection{Research Design}

The survey design was used in carrying out the study. The choice of this design was informed by the fact that the study was designed to seek information and the opinion of respondents on the counseling implication of transformation of CS in Nigeria higher education.

\subsection{Area of Study}

The study covered some federal universities in the South-South geo-political zone of Nigeria. These include: University of Benin, Edo State, University of Uyo, Akwa Ibom State, University of Calabar, Cross River State, and University of Port Harcourt, Rivers State.

\subsection{Population of the Study}

The population of the study comprised a total of 179 respondents made up of 140 challenged student counselors and 39 professional counselors. 


\subsection{Sampling and Sampling Technique}

There was no sampling since the population was manageable.

\subsection{Instrument for Data Collection}

Structured questionnaires were developed by the researcher. The questionnaire contained twenty items on a four point response scale of strongly agree, agree, disagree and strongly disagree options, weighing 4, 3, 2, and 1 respectively.

\subsection{Validation and Reliability of the Instrument}

The questionnaire was face validated by five experts; two in guidance and counseling in University of Nigeria, Nsukka, Enugu State, one in measurement and evaluation in University of Nigeria, Nsukka, and two in Guidance and counseling in Nnamdi Azikiwe University Awka, Anambra State, Nigeria. The questionnaire was then trial-tested using five professional counselors (PC) and student counsellors in University of Nigeria, Nsukka, Enugu state, which is outside the target sample. The internal consistency of counseling implication of transformation of challenged students in Nigeria higher education were determined using Chrombach Alpha and it yielded an Alpha value of 0.97 which was considered high enough.

\subsection{Method of Data Collection}

The researcher and seven trained research assistants engaged in the distribution and retrieval of the instrument designed for the study. Direct approach by hand was employed to ensure maximum return of the questionnaires.

\subsection{Method of Data Analysis}

The data collected for the study were analysed using mean in answering the research questions. A mean of 2.5 and above was accepted, while any mean less than 2.5 was rejected.

\section{Result}

Research Question 1: What are the counseling implications of the transformation of challenged students in Nigeria higher education?

Table 1. Counseling implication of the transformation of challenged students in Nigeria higher education

\begin{tabular}{|l|l|l|l|}
\hline S/N & Items & Means & Remark \\
\hline 1. & Professional development & 3.98 & SA \\
\hline 2. & Expression of sense of value & 3.98 & SA \\
\hline $3 .$. & Intrinsic abilities & 3.98 & SA \\
\hline 4. & Discipline & 3.97 & SA \\
\hline 5. & Training with assistive technology & 3.97 & SA \\
\hline 6. & National Development & 3.96 & SA \\
\hline 7. & Collaboration in a globalized world & 3.94 & SA \\
\hline 8. & Teacher training & 3.75 & SA \\
\hline 9. & Critical thinking/problem solving & 2.58 & A \\
\hline 10. & Ultimate goal/radical change & 2.56 & A \\
\hline
\end{tabular}

From Table 1 above items 1, 2, 3, 4 and 5 obtained mean scores of $3.75-3.98$ indicating that the respondents strongly agreed that professional development, values, intrinsic abilities, discipline, assistive technology, national development, globalized world, and teacher training are counseling implication of transformation of challenged students in Nigeria higher education.
However, items 9 and 10 with mean scores of $2.58-$ 2.56 showed that respondents agreed that critical thinking/problem solving and ultimate goal/radical change are counseling implications of transformation of challenged students in Nigeria higher education.

Research Question 2: What are the various counseling skills a professional counselor utilizes in the transformation of challenged students in Nigeria higher education? 
Table 2. The various counseling skills a professional counselor utilizes in transformation of challenged students in Nigeria higher education

\begin{tabular}{|l|l|l|l|}
\hline S/N & Items & Means & Remark \\
\hline 1. & Orientation & 3.98 & SA \\
\hline 2. & Transformation & 3.98 & SA \\
\hline 3. & Evaluation & 3.96 & SA \\
\hline 4. & Managerial & 3.85 & SA \\
\hline 5. & Self-analysis & 3.85 & SA \\
\hline 6. & Creative & 3.84 & SA \\
\hline 7. & Problem-solving & 3.82 & SA \\
\hline 8. & Communication & 2.78 & A \\
\hline 9. & Time management & 2.74 & A \\
\hline 10. & $\begin{array}{l}\text { Occupational analysis is not a counseling skill utilized by } \\
\text { professional counselors in transformation of challenged students } \\
\text { in Nigeria higher education. }\end{array}$ & & SD \\
\hline
\end{tabular}

From Table 2 above, items 1, 2, 3, 4 and 5 obtained mean scores of 3.82-3.98. This shows that respondents strongly agreed that orientation, transformation, evaluation, managerial skill, selfanalysis, creative and problem-solving skills are counseling skills utilized by professional counselors in transformation of challenged students in Nigeria higher education. Items 8 and 9 obtained mean scores ranging from 2.74 and 2.78. This shows that respondents agree that communication and time management are counseling skills utilized by professional counselors in transformation of challenged students in Nigeria higher education. However, item 10 obtained a mean score of 1.00 . This shows that respondents are yet to understand that occupational analysis is one of the best counseling skill for transformation of challenged students in Nigerian higher education.

\section{Discussion}

Professional development, values, intrinsic abilities, discipline, and assistive technology are counseling implication of transformation of challenged students in Nigeria higher education. This is in line with Shaw [1] who sees education as an avenue for teacher training, professional development (i.e training and retraining of the teachers). It is also in line with Onyilofor [4] who adjudges that in Nigeria, education has been a major means through which societies ensure their younger generation (including the challenged students) acquire necessary skills, attitudes, professional development and values that enable them function effectively in the society. Fafunwa [2] and Onyilofor [5] in support of the above assertions define education as a procedure by which challenged students develop intrinsic abilities, interests, potentialities, values and skills which enable the challenged students have changes in conduct enabling them become well-adjusted and well- focused citizens with positive mind set and action in the community they find themselves. Furthermore, Onyilofor [4] posits that the professional counselor should utilize best administration, thinking skills, training programme, action research skills, orientation, planning, time management skill, and use of assistive technology skill for transformation of challenged students in Nigeria higher education. Orientation, transformation, evaluation, managerial skill and self-analysis skill are counseling skills utilized by professional counselor in transformation of challenged students in Nigeria higher education. This is in line with Agwu [14] who states that transformation is exploitation of natural resources, the choice of type of investment and orientation of technological and institutional modification. Similarly, Okyere and Adam [28] as cited in Heward and Orlanry referred to special education as individually planned, systematically and carefully evaluated instruction that helps exceptional learners achieve the greatest possible personal selfsufficiency and success in the present and future environments. The researcher, further states that higher education in Nigeria should undergo transformation through the role of the professional counselors if they are to become managers in their areas of specialization. Also Parson as cited in Patton and McMahon [26] posits the role of the professional counselor to be in three categories namely; selfanalysis, occupational analysis, and true reasoning or counseling to relate personal and occupational information.

\section{Recommendation}

The following recommendations were drawn:

1. Government at all levels, philanthropists, and various universities; should ensure that the challenged students and professional counselors are encouraged and financed to attend conferences, workshops, symposiums and in-service training both 
in Nigeria and abroad at least twice a year so as to enhance their professional responsibilities.

2. Professional counsellors and expert teachers should utilize various counselling skills required to effectively transform challenged students into better citizens.

3. The local, state and federal government should give the challenged students scholarships and special packages to serve as incentives.

4. Government at all levels should equip special education and training centres with the state-of-theart assistive technologies to facilitate effective teaching and learning.

5. Government at all level should ensure the full participation of challenged students, parents/guardians of challenged students, expert teacher/professional counselors, NGOs and other stakeholders within the system in planning, brain storming, organizing, supervising, monitoring and implementing activities in the higher education system especially relating to transformation of challenged students.

\section{Conclusion}

Conclusively, by implication, transformation of challenged students in Nigeria higher education cannot be over emphasized. This implies that if the professional counselor trains the challenged students well, when they graduates, they will be valuable, disciplined, their intrinsic abilities will be fully developed, and are able to cope with the challenges they face in their daily living. Various counselling skills have been identified as beneficial in the training of the challenged students. These skills include orientation, evaluation, managerial, timemanagement, creative, communication, self-analysis skills among others. It was therefore recommended that both government and non-government organizations should donate and equip classrooms and counselling centres where challenged students are trained with modern assistive technologies. The challenged students, expert teachers and professional counsellors should regularly be developed professionally through sponsorship and scholarships to enable them compete favourably with their counterparts all over the world.

\section{References}

[1] Agarwal, A., (2012). Essay on the Role of Education in Society. Retrieved from http://www.preservearticles.com /201107048804/essay-on-the-role-of-education-in-society. Html (Access Date: 5 March, 2015).

[2] Shaw S.R., (2005). The devolution of interest in slow learners can we continue to ignore NASP Communique www.nasp-online.org/ publication cq 212 slow learner html (Access Date: 2 March, 2015).
[3] Onyilofor F.N.C., (2013). Reforming social studies curriculum for inclusive higher education in Nigeria: the role of counseling. Nigeria Journal of Social Studies and Civic Education 3(1).

[4] Fafunwa X.B., (1980). History of Education in Nigeria George Allen and Unwin Ltd London.

[5] Onyilofor F.N.C., (2012) The role of counselors in curriculum transformer in education of the visually challenged students (VCS): Implication for Globalization. Journal of Faculty of Education University of Nigeria Nsukka 12(1).

[6] Onyilofor F.N.C., (2013). Repositioning Guidance and Counseling and curriculum innovation in higher education in Nigeria Journal of Internal Education Research second quarter.

[7] Mgbodile, T. O. and Iwuh I.I., (2000). Understanding Children: A better way to child's useful bringing Enugu, Magnet Business Enterprises.

[8] Aglazor G.N., (2015). The Phenomenon called globalization. A look at teacher education in Nigeria. A lead paper presented at the 2015 annual conferences of Institute of Education University of Nigeria, Nsukka August 25th - 28th 2015.

[9] Nnadi C., (2011). Repositioning Adult and non-formal education for national development through curriculum reform. Journal of educational research II (1).

[10] Onyilofor F.N.C., (2013). Counseling students with special needs in higher education for national development in Nigeria. Journal of education. 5.

[11] Disability World, (2015). Famous Disable People.

[12] Onyilofor F.N.C., (2011). Counselor's role in entrepreneurship education for students in tertiary institution in Nigeria. Nigeria Vocational Association Journal.

[13] Obanya P., (2011). Educating for transformation. Key Note presentation, International Conference on Education. University of Nigeria, Nsukka.

[14] Agwu E.A., (2015). Promoting responsible living among individual and families: key drivers and challenges at the family level. Journal of Home Economics Research Association of Nigeria.

[15] Nigerian University Commission, (2011). Benchmark minimum. Academic standards for undergraduate programmes in Nigeria universities GST entrepreneurship.

[16] www.Agegee.org, (Access Date: 1 October, 2015)

[17] Italian Ministry of Education, (2015). Higher Education, Italy.

[18] Mghweno P.E. Mghweno. L.R. \& Baguna P., (2014). Access of guidance and counseling services and its influence on students' school life and career choice. African journal of Guidance and counseling 1(1) 7-15. 
[19] Anyamene A.N. Owokolo C.N Anyachebdu E.F., (2012). Availability and use of information and communication Technology resources for counseling university students in south east state. International journal of humanities and social sciences.

[20] Palmer B., (2007). The use of computer technology in university teaching and learning: A critical perspective. San Francisco Josey bass.

[21] United Nations Educational Scientific and Cultural Organization, (2002). Handbook on career counseling: A practical manual for developing implementing and assessing career counseling higher education settings.

[22] Onyilofor, F.N.C., (2013). Transformation and Entrepreneurship education of the special needs students in Nigeria higher education: counseling implication. National transformation through entrepreneurship education Timex enterprise.

[23] Stearns, P.N., (2009). globalization in world history. Rantledga. NY.

[24] Obi M.C., Oye N.D., Mohd, T.N., Benice V., (2012). The impact of ICT on career counseling services: A case of study of Nigerian Secondary Schools.1(1) 1-16.

[25] Parsons F., (1909). Choosing a vocation. Boston, MA, US: Houghton Mifflin and Company.

[26] Patton, W. \& McMahon, A. (2001). Senior Studentse View on Career Information: what can the most useful and what would they like. Australian Journal of Career Development, 10 (1) $32-36$.

[27] www.tech.com, "What is special education". Access date: 8 August 2014.

[28] Okyere B.A. \& Adams J.S., (2003). Introduction to special education: an introduction special education: An African perspective. Accra: Adweinsa publications Ltd.

[29] Christopher M.V., (2012). Teacher preparation programme in special Needs education in Nigeria. The Journal of the National center for exceptional children 14(1). 